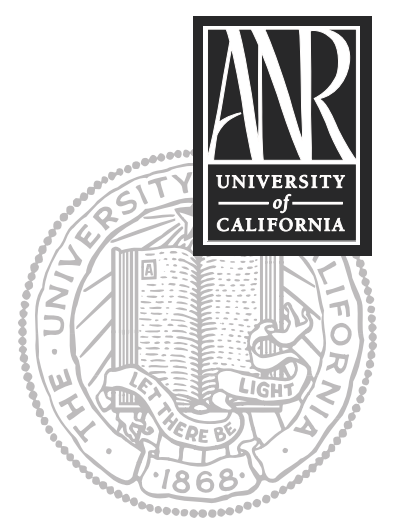

UNIVERSITY OF CALIFORNIA

Division of Agriculture and Natural Resources http://anrcatalog.ucdavis.edu

\title{
Growing Processing Cling Peaches in California: An Overview
}

MAXWELL NORTON, University of California Cooperative Extension Farm Advisor, Merced County; ROGER DUNCAN, University of California Cooperative Extension Farm Advisor, Stanislaus County; JANINE HASEY, University of California Cooperative Extension Farm Advisor, Sutter and Yuba Counties

California produces 99 percent of the nation's processing cling peaches. Other major peach-producing countries are China, Greece, Spain, Thailand, and Chile. All of California's cling peach acreage is located in the Central Valley. As of 2006, the counties with the most acreage are, in descending order Sutter, Stanislaus, Yuba, Merced, Fresno, Butte, and San Joaquin.

\section{PLANNING THE ORCHARD}

\section{Potential for profit}

During orchard development, yield potential is directly related to how quickly trees fill the space in an orchard, but at maturity yield potential is the same in both highdensity and conventional systems. High-density peach orchards can obtain higher yields more quickly than conventionally spaced orchards, but they have higher initial planting costs due to the greater number of trees per acre. High-density orchards can yield 2 to 3 tons per acre in their second season; peaches in conventionally spaced orchards are often first harvested their third year, and approximately 6 tons per acre can be anticipated in a well-managed block. Potential yields for subsequent years may be 12 tons for the fourth, 15 tons for the fifth, 18 tons for the sixth, and 20 tons thereafter. From 2001 to 2005, average grower returns in California were $\$ 237$ per ton. Most processor contracts have significant bonuses and penalties for quality. Cling peach orchards are generally replanted every 15 to 18 years.

\section{Production Costs}

The greatest production costs are for pruning, thinning, pest management, and harvesting. The University of California Cooperative Extension (UCCE) has developed cost studies that show generalized peach production costs. UC cost studies are available at UCCE offices, some financial institutions, and free on the Internet at the UC Davis Department of Agricultural and Resource Economics Web site, http://coststudies.ucdavis.edu.

\section{Climate}

Peaches require adequate winter chilling (approximately 800 to 900 hours of temperatures below $45^{\circ} \mathrm{F}$, depending on the variety) for normal flowering and fruit set. Bloom normally occurs in early March; hot, dry conditions during bloom can result in a shortened bloom period and reduced crop. Wet weather during bloom can reduce set or induce blossoming and subsequent fruit disease. For best yield and quality, a warm, dry growing season is desirable. Spring frost is less of a problem with processing peaches than with earlier-blooming crops such as almonds and fresh-market peaches, but planting in frost-prone areas may require the additional expense of frost protection. 


\section{Suitable Soils}

Peaches are most productive on well-drained, uniform, sandy loam soils. Optimal soil textures range from sand to loam. Peaches can be grown on clay loam soils, but obtaining size may be a challenge and irrigation must be closely managed. Although county soil surveys provide information on soils, they often do not show adequate detail. Use a backhoe to dig several holes on the prospective property in areas where you might expect differences in soil type. Contact your UCCE office for assistance if you are not familiar with evaluating soils. Look for anything that might restrict water movement and root growth such as clay pans, hardpans, silt pans, stratification, and high water tables. Soil chemical analysis gives clues to problems with $\mathrm{pH}$, salinity, and toxicities from boron (B), sodium (Na) and chloride $\left(\mathrm{Cl}^{-}\right)$. Correcting soil problems before planting is more effective and less expensive than trying to correct problems after an orchard is established.

\section{ESTABLISHING THE ORCHARD}

Good planning is essential to the efficient operation and ultimate profitability of the orchard. Before planting, it is important to install an irrigation system, level the land to promote uniform water distribution in flood-irrigated orchards, deep till, rip or backhoe to destroy or mix impervious layers in the soil profile, fumigate based on nematode samples, and choose the proper peach variety and rootstock. Allow at least 1 year of lead time before planting to complete these operations.

A wide range of tree and row spacings are in use. There is a general trend toward higher densities and shorter trees that are less reliant on ladders for harvesting. A common spacing in conventionally planted orchards is 16 to 20 feet apart for trees in the row and 18 to 22 feet between rows. Tree spacing in high-density orchards is typically 6 to 8 feet between trees in the row and 16 to 18 feet between rows. Higher-density plantings may require modified equipment. It is recommended that the trees be trained to accommodate mechanical harvesters if needed.

\section{Irrigation}

Like other tree crops, mature peach orchards with vegetation between the rows use about 40 acre-inches of water per year, including rainfall. Peak water use in midsummer is about 0.3 inches per day. Including a safety factor for exceptionally hot, windy weather and interrupted water supplies, your irrigation system should be designed to deliver at least 0.5 inches per day.

The type of irrigation system used is not as important as how well it is designed and managed. The system should uniformly distribute water to each tree. Which system to use depends on the availability and cost of water, the type and depth of soil, the amount of land leveling needed, and any special management problems present.

A large percentage of recently developed peach orchards use two drip hoses per row with in-line drippers that can better tolerate being walked on by laborers. Planting trees on a berm (a raised area of soil along a tree row) and flooding the middles is also common; it usually involves a lower initial cost and is cheaper to operate and maintain. Impact sprinklers are rarely used. Low-volume microsprinklers and microjets may increase humidity in the orchard, which can lead to disease problems. These sprinklers may also be less suited for the large amount of foot traffic around trees during pruning, thinning, and harvesting. Low-volume irrigation systems can be used for delivering nitrogen, potassium, and other fertilizers to trees. 


\section{Varieties}

All peach varieties are of the genus and species Prunus persica. The flowers are selffertile, and bees are not needed to improve sets. Processing peaches for canning are grouped into four maturity groups: extra early, early, late, and extra late. A common strategy is to have a range of varieties that ripen over a long period to reduce peak labor demands. Peaches can have a slight tendency to alternate bearing (a heavy crop followed by a light crop the next year) when crop size is not controlled by pruning or thinning. Recently, new varieties have been introduced by the University of California, growers, and independent plant breeders. For information on new varieties contact your local UCCE Farm Advisor.

\section{Rootstocks}

The most commonly used rootstocks in California are Lovell and Nemaguard. Some nurseries have proprietary rootstocks as well. Rootstock decisions are based on soil type and problems such as high $\mathrm{pH}$, salinity, soil pathogens, and parasitic nematodes. Almost all rootstocks currently used are considered to be vigorous and will produce a full-sized tree. Nemaguard is resistant to the most common strains of root knot nematode but is susceptible to ring nematode, which is associated with bacterial canker complex, a serious disease of peach trees planted on sandy soils.

\section{Equipment}

Equipment commonly needed for a 40-acre orchard might include a 40- to 60-horsepower wheel tractor; 9-foot offset wheel disc or a mower/brush shredder; 3-point push scraper; weed sprayer; furrower (if you furrow-irrigate); 3-point forks for moving bins; hydraulic pull scraper; orchard sprayer; forklift; and several bin carriers.

\section{MANAGING THE ORCHARD}

\section{Training and Pruning}

Train peach trees to provide a strong framework capable of supporting large crops and accommodating harvesting equipment. Peaches need to be pruned every year to maintain consistent, uniform yields and good fruit size. Most trees benefit from having a rope or wire placed around the scaffolds to prevent breakage from the heavy crops.

\section{Orchard Floor Management}

Weed management in peaches is similar to that of other tree crops. Common management systems usually include weed control with herbicides around the base of the tree or along the berm combined with discing or mowing the centers. Cover crops between the tree rows are becoming more common.

\section{Fertilizing}

Processing peaches are commonly fertilized at a rate of 50 to 100 pounds per acre of actual nitrogen $(\mathrm{N})$ applied annually during the growing season, depending on tree vigor. Other than nitrogen, zinc ( $\mathrm{Zn}$ ) is usually the element most likely to become deficient on sandy soils, and foliar sprays of zinc are commonly applied. Peaches are heavy users of potassium (K), and it may become deficient if soils are inherently low in potassium. Potassium deficiency is best corrected by massive soil applications of potassium every 3 to 5 years or with annual soil application of lower maintenance rates. Potassium chloride can be used if soils are sandy and the chloride can be leached. Potassium sulfate is also used and does entail the risk of chloride toxicity. 


\section{Thinning}

The Central Valley's climate is excellent for heavy peach production, but profitable peach growing is based on the grower's ability to consistently produce moderate crops of well-sized fruit. Excessive crops on individual trees generally result in small fruit of less value. Growers must use a combination of pruning and fruit thinning to regulate crop and fruit size. Currently, thinning is performed by hand at considerable cost. UC specialists are experimenting with mechanical and chemical thinning techniques to reduce cost.

\section{PEST MANAGEMENT}

Insect pests that require annual treatment include peach twig borer (PTB) and oriental fruit moth (OFM). Other insect pests such as San Jose scale, oblique banded leaf roller (OBLR), omnivorous leafroller (OLR), stink bug, lygus bug, calocoris, katydids, mites, and leaf-footed plant bug occasionally need treatment and should be regularly monitored. Insect pests can vary with region, so inquire with local UCCE Farm Advisors or pest control advisers.

With warm, wet weather during bloom, blossom brown rot can cause major economic losses. Blossom brown rot can be followed by fruit brown rot as fruit ripen, especially if summer rainfall occurs. Shot hole can damage buds, leaves, twigs, and fruit. Peach leaf curl (PLC) must be controlled during the dormant season. Other lesscommon diseases that can damage fruit are powdery mildew and rust. Diseases that can damage the tree include bacterial canker, Armillaria root rot, and Phytophthora crown and root rot.

Nematodes, microscopic worms that feed in and on the roots, are associated with sandy soils and locations where trees have grown previously. The best control is thorough removal of old roots, backhoeing tree sites, and preplant fumigation.

Several excellent UC ANR publications that cover peach management practices in detail are available from your local UCCE office. For a typical pest management program, obtain a copy of Seasonal Guide to Environmentally Responsible Pest Management Practices in Peaches and Nectarines (ANR Publication 21625). Also consult the continuously updated UC IPM Guidelines for Peaches (see the IPM Web site, http://www.ipm.ucdavis.edu/PMG/selectnewpest.peach.html). Detailed information on the pests and diseases of canning peaches can be also found in the book IPM for Stone Fruits (ANR Publication 3389).

\section{HARVESTING}

Optimal harvest timing is critical to maximizing fruit quality and yield. Since fruit does not ripen uniformly, two or three pickings based on color may be required. This may be especially true on sandier soils. Obtaining sufficient labor can be a significant challenge in some years. If mechanical harvesting is used, a first picking by hand may be done based on color with a machine harvest to follow when the rest of the fruit is mature. In-field hand-sorting of small or damaged fruit is common.

Successful mechanical harvesting is predicated on having machines that are well designed, well maintained, and carefully operated. Harvesters are usually operated in the early morning hours when fruit temperatures are low and fruit are less prone to injury.

\section{MARKETING}

Cling peaches are marketed to a processor, usually under a multiyear contract. Cling peaches are used to produce canned and frozen peaches, juice, and baby food prod- 
ucts. Most are processed in California, with some going to other states and Mexico for processing. A list of processors is available from the California Canning Peach Association or the California Cling Peach Board. Talk to as many companies as possible and ask other growers about reliability and reputation. A lawyer should review any contract, detailing the responsibilities and protections of all the parties involved. Quality standards are set by an agreement between the processors and the California Canning Peach Association, and the grading process is often administered by a thirdparty organization under contract with the processor.

Many growers are members of the California Canning Peach Association, which is a bargaining association that negotiates on behalf of its grower members. The California Cling Peach Board administers industry-wide promotion, government and trade relations, market maintenance, and production research.

\section{METRIC CONVERSIONS}

\begin{tabular}{|c|c|c|c|}
\hline English & $\begin{array}{l}\text { Conversion factor for } \\
\text { English to Metric }\end{array}$ & $\begin{array}{c}\text { Conversion factor for } \\
\text { Metric to English }\end{array}$ & Metric \\
\hline inch (in) & 2.54 & 0.394 & centimeter $(\mathrm{cm})$ \\
\hline foot $(\mathrm{ft})$ & 0.3048 & 3.28 & meter $(\mathrm{m})$ \\
\hline acre $(\mathrm{ac})$ & 0.4047 & 2.47 & hectare (ha) \\
\hline acre-inch (ac-in) & 102.8 & 0.0097 & cubic meter $\left(\mathrm{m}^{3}\right)$ \\
\hline pound (lb) & 0.454 & 2.205 & kilogram (kg) \\
\hline ton $(T)$ & 0.907 & 1.1 & metric ton $(\mathrm{t})$ \\
\hline pound per acre (lb/ac) & 1.12 & 0.89 & kilogram per hectare $(\mathrm{kg} / \mathrm{ha})$ \\
\hline ton per acre (T/ac) & 2.24 & 0.446 & metric ton per hectare (t/ha) \\
\hline Fahrenheit $\left({ }^{\circ} \mathrm{F}\right)$ & ${ }^{\circ} \mathrm{C}=\left({ }^{\circ} \mathrm{F}-32\right) \div 1.8$ & ${ }^{\circ} \mathrm{F}=\left({ }^{\circ} \mathrm{C} \times 1.8\right)+32$ & Celsius $\left({ }^{\circ} \mathrm{C}\right)$ \\
\hline
\end{tabular}

\section{WHERE TO GET MORE INFORMATION}

The UCCE maintains offices in most counties, with Farm Advisors who specialize in the crops grown in the county. They can be contacted free of charge for information and assistance (a list of offices can be found at http://ucanr.org/ce.cfm). Prospective growers are urged to get information from UC before entering into commercial peach growing. UC also publishes books, leaflets, and online materials on farming practices; a free catalog is available at their Web site, http://anrcatalog.ucdavis.edu, and from local Cooperative Extension offices.

The California Cling Peach Board can be contacted at 531-D North Alta Avenue, Dinuba, CA 93618; phone 559-591-5744; Web site, http://www.calclingpeach.com/.

The California Canning Peach Association has representatives in all the peachgrowing regions. They can be contacted at 2300 River Plaza Drive, Suite 110, Sacramento, CA 95833; phone 916-925-9131; Web site, http://calpeach.com/.

\section{FOR FURTHER INFORMATION}

To order these products, visit our online catalog at http://anrcatalog.ucdavis.edu. You can also place orders by mail, phone, or FAX, or request a printed catalog of publications, slide sets, CD-ROMs, and videos from

University of California

Agriculture and Natural Resources

Communication Services

6701 San Pablo Avenue, 2nd Floor

Oakland, California 94608-1239

Telephone: (800) 994-8849 or (510) 642-2431

FAX: (510) 643-5470

E-mail inquiries: danrcs@ucdavis.edu 


\section{$\cup \cup_{P \in R}$ REVIEWED}

\section{Publication 8276}

This publication has been anonymously peer reviewed for technical accuracy by University of California scientists and other qualified professionals. This review process was managed by the ANR Associate Editor for Pomology, Viticulture, and Subtropical Horticulture.

ISBN-13: 978-1-60107-513-0

(C)2007 The Regents of the University of California

Division of Agriculture and Natural Resources

All rights reserved.

No part of this publication may be reproduced, stored in a retrieval system, or transmitted, in any form or by any means, electronic, mechanical, photocopying, recording, or otherwise, without the written permission of the publisher and the authors.

The University of California prohibits discrimination or harassment of any person on the basis of race, color, national origin, religion, sex, gender identity, pregnancy (including childbirth, and medical conditions related to pregnancy or childbirth), physical or mental disability, medical condition (cancer-related or genetic characteristics), ancestry, marital status, age, sexual orientation, citizenship, or status as a covered veteran (covered veterans are special disabled veterans, recently separated veterans, Vietnam era veterans, or any other veterans who served on active duty during a war or in a campaign or expedition for which a campaign badge has been authorized) in any of its programs or activities. University policy is intended to be consistent with the provisions of applicable State and Federal laws.

Inquiries regarding the University's nondiscrimination policies may be directed to the Affirmative Action/Staff Personnel Services Director, University of California, Agriculture and Natural Resources, 1111 Franklin Street, $6^{\text {th }}$ Floor, Oakland, CA 94607-5201, (510) 987-0096. For information about ordering this publication, telephone 1-800-994-8849.

xm-pr-8/07-SB/CM 